\title{
Fortbcoming Publications
}

\section{CUSTOMARY LAW OF THE HAYA TRIBE}

TANGANYIKA TERRITORY

By H. CORY and M. M. HARTNOLL

PUBLISHED FOR THE INTERNATIONAL AFRICAN INSTITUTE BY

PERCY LUND HUMPHREYS \& CO.

BEDFORD SQUARE, LONDON

THE DYNAMICS OF CLANSHIP

AMONG THE TALIENSI

Being the first part of a study of the social structure of a trans-Volta tribe

By MEYER FORTES

PUBLISHED FOR THE INTERNATIONAL AFRICAN INSTITUTE BY THE OXFORD UNIVERSITY PRESS

\section{AN AFRICAN ARISTOCRACY RANK AMONG THE SWAZI \\ By HILDA KUPER}

PUBLISHED FOR THE INTERNATIONAL, AFRICAN INSTITUTE BY THE OXFORD UNIVERSITY PRESS

INTERNATIONAL INSTITUTE OF AFRICAN LANGUAGES AND CULTURES

Chairman: THE RT. HON. LORD HAILEY

Director and Acting Secretary-General: PROFESSOR DARYLL FORDE Secretary: MRS. B. E. WYATT

Hon. Treasurer: H. G. JUDD, ESQ.

Hon. Azuditors: MFSSRS. MANN, JUDD, GORDON \& CO.

Hon. Solicitors: MESSRS. LAWRENCE JONES \& CO.

Bankers

MESSRS. BARCLAYS BANK (DOMINION, COLONIAL \& OVERSEAS)

\section{Central Office}

Seymour House, 17 Waterloo Place, London, S.W. 1 


\section{FOR USE IN}

AFRICA

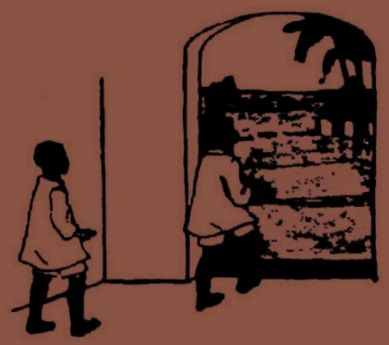

THE African Life series is designed 1 to help the African child in learning to speak and read English. The material, which is taken from his own surroundings, comes within the limits of his experience. The method behind the books is 'direct', based upon the principles of see, say, do. Its purpose is to enable the child to think and to express his thoughts in simple English, related to the world in which he lives. A Teachers' Manual discusses the classroom development of material in the Readers.

\section{A FR I CAN L I F E SERIES}

PRIMER

FIRST READER

SECOND READER

THIRD READER

TEACHERS' MANUAL
Is. Id.

Is. $4 d$.

Is. $6 d$.

Is. $6 d$.

25.

\section{GINN AND COMPANY LTD. QUEEN SQUARE, LONDON, W.C. I}

Printed in Creat Britain at the University Press, Oxford, by John Johnson, Printer to the University 